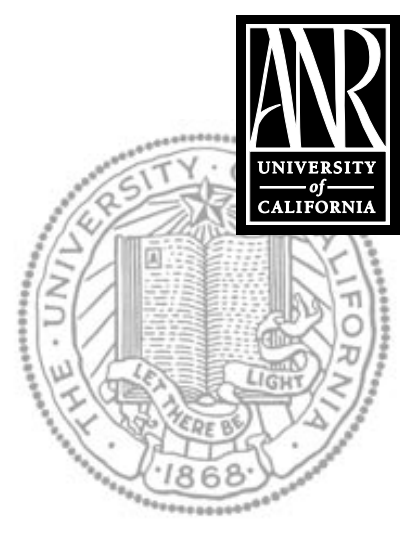

UNIVERSITY OF CALIFORNIA

Division of Agriculture and Natural Resources

http://anrcatalog.ucdavis.edu

\title{
Common Incubation Problems: Causes and Remedies
}

\section{R. A. ERNST, F. A. BRADLEY, M. E. DELANY, U. K. ABBOTT, and}

R. M. CRAIG, Animal Science Department, University of California, Davis

I $\mathrm{t}$ is advisable to investigate the cause or causes of problems when poultry hatches are below expectations. This publication can be helpful in determining the cause of incubations that fail and hatches that are below expected levels or have poor chick quality. Diagnose the problem by examining all eggs that fail to hatch or poor-quality chicks, or if not practical, a representative sample of them. The tables below suggest causes of problems that may commonly be observed. Click on highlighted terms for a link to the glossary at the end of this publication.

\section{OBSERVATION: EXCESSIVE INFERTILITY FOR SPECIES}

\begin{tabular}{|l|l|l|}
\hline Problem & Causes & Remedies \\
\hline True infertility. & $\begin{array}{l}\text { Poor insemination } \\
\text { technique. }\end{array}$ & $\begin{array}{l}\text { Inseminate more frequently at prop- } \\
\text { er depth with good semen. }\end{array}$ \\
\cline { 2 - 3 } & $\begin{array}{l}\text { Hens not inseminated; } \\
\text { wrong male to female } \\
\text { ratio. }\end{array}$ & $\begin{array}{l}\text { Inseminate hens; replace males; use } \\
\text { more males. }\end{array}$ \\
\cline { 2 - 3 } & $\begin{array}{l}\text { Preferential mating in pen } \\
\text { matings. }\end{array}$ & Mate hen with different male. \\
\cline { 2 - 3 } & Male sterility. & Change males. \\
\cline { 2 - 3 } & Males not mating. & $\begin{array}{l}\text { Check for disease, nutrition prob- } \\
\text { lems, foot problems, and social } \\
\text { dominance of females; provide a } \\
\text { healthy environment for the breed- } \\
\text { ing flock; check for heat stress, as it } \\
\text { often reduces mating activity. }\end{array}$ \\
\cline { 2 - 3 } & $\begin{array}{l}\text { Use young males; reinforce natural } \\
\text { mating with artificial insemination } \\
\text { if old, valuable males must be used. }\end{array}$ \\
\cline { 2 - 3 } & Males too old.
\end{tabular}

\section{OBSERVATION: OVER $3 \%$ DEAD IN FIRST 3 DAYS OF} INCUBATION

\begin{tabular}{|l|l|l|}
\hline Problem & Causes & Remedies \\
\hline $\begin{array}{l}\text { Fertile, preovipositional } \\
\text { death. }\end{array}$ & Inbred strains. & $\begin{array}{l}\text { Avoid excessive inbreeding; use } \\
\text { young males. }\end{array}$ \\
\cline { 2 - 3 } & $\begin{array}{l}\text { Parthenogenesis in } \\
\text { turkeys. }\end{array}$ & $\begin{array}{l}\text { Do not use genetic stocks showing } \\
\text { a high incidence of parthenogenesis } \\
\text { as breeders. }\end{array}$ \\
\hline $\begin{array}{l}\text { Fertile, no development } \\
\text { (FND). }\end{array}$ & $\begin{array}{l}\text { Eggs stored at a tempera- } \\
\text { ture that is too low. }\end{array}$ & $\begin{array}{l}\text { Store hatching eggs at } 55^{\circ} \mathrm{F} \text { to } 68^{\circ} \mathrm{F} \\
\left(12.8^{\circ} \text { to } 20.0^{\circ} \mathrm{C}\right) . \text { See Ernst } 2004 .\end{array}$ \\
\cline { 2 - 3 } & Eggs stored too long. & $\begin{array}{l}\text { Store chicken, pheasant, duck, } \\
\text { goose, and quail eggs no longer } \\
\text { than 1 week; store turkey and par- } \\
\text { tridge eggs no longer than 2 weeks. }\end{array}$ \\
\hline
\end{tabular}




\section{OBSERVATION: OVER 3\% DEAD IN FIRST 3 DAYS OF} INCUBATION, Cont.

\begin{tabular}{|c|c|c|}
\hline Problem & Causes & Remedies \\
\hline $\begin{array}{l}\text { Fertile, preovipositional } \\
\text { death. }\end{array}$ & $\begin{array}{l}\text { Eggs washed at a temper- } \\
\text { ature that is too high. }\end{array}$ & $\begin{array}{l}\text { Dry-clean eggs; eliminate dirty eggs; } \\
\text { lower temperature of wash water } \\
\text { to } 110^{\circ} \text { to } 120^{\circ} \mathrm{F}\left(43.3^{\circ} \text { to } 48.9^{\circ} \mathrm{C}\right) \text {; } \\
\text { produce clean eggs. }\end{array}$ \\
\hline Positive development (PD). & $\begin{array}{l}\text { Poor collection sched- } \\
\text { ule during hot or cold } \\
\text { weather. }\end{array}$ & $\begin{array}{l}\text { When temperature in house or nest } \\
\text { box exceeds } 80^{\circ} \mathrm{F}\left(26.6^{\circ} \mathrm{C}\right) \text {, collect } \\
\text { eggs } 4 \text { or more times during the day. }\end{array}$ \\
\hline $\begin{array}{l}\text { Blastoderm without } \\
\text { embryo (BWE). }\end{array}$ & $\begin{array}{l}\text { Improper storage tem- } \\
\text { perature. }\end{array}$ & $\begin{array}{l}\text { Store eggs at } 55^{\circ} \text { to } 68^{\circ} \mathrm{F}\left(12.8^{\circ} \text { to }\right. \\
\left.20.0^{\circ} \mathrm{C}\right) \text {. See Ernst } 2004 .\end{array}$ \\
\hline \multirow[t]{7}{*}{ Cystic embryos. } & Eggs stored too long. & $\begin{array}{l}\text { Store chicken, pheasant, duck, } \\
\text { goose, and quail eggs no longer } \\
\text { than } 1 \text { week; store turkey and par- } \\
\text { tridge eggs no longer than } 2 \text { weeks. }\end{array}$ \\
\hline & $\begin{array}{l}\text { Rough handling or ship- } \\
\text { ping procedures. }\end{array}$ & $\begin{array}{l}\text { Handle eggs carefully from time } \\
\text { eggs are gathered until chicks or } \\
\text { poults are hatched. }\end{array}$ \\
\hline & $\begin{array}{l}\text { Diseased flock (e.g., } \\
\text { Mycoplasma spp., } \\
\text { Newcastle disease). }\end{array}$ & $\begin{array}{l}\text { Inspect flock for general and specif- } \\
\text { ic health conditions; seek veterinary } \\
\text { assistance. }\end{array}$ \\
\hline & $\begin{array}{l}\text { Aged or abnormal sper- } \\
\text { matozoa. }\end{array}$ & $\begin{array}{l}\text { Check insemination technique; use } \\
\text { young males. }\end{array}$ \\
\hline & Eggs from inbred flock. & $\begin{array}{l}\text { Some losses are unavoidable with } \\
\text { inbreeding; change males or intro- } \\
\text { duce new genetic stock. }\end{array}$ \\
\hline & $\begin{array}{l}\text { Improper egg storage } \\
\text { temperature or preincuba- } \\
\text { tion temperature. }\end{array}$ & $\begin{array}{l}\text { Do not allow eggs to preincu- } \\
\text { bate: they should not exceed } 80^{\circ} \mathrm{F} \\
\left(26.6^{\circ} \mathrm{C}\right) \text {; use setter temperature of } \\
99.5^{\circ} \text { to } 100^{\circ} \mathrm{F}\left(37.5^{\circ} \text { to } 37.8^{\circ} \mathrm{C}\right) \text {; } \\
\text { check egg storage temperature. }\end{array}$ \\
\hline & $\begin{array}{l}\text { Eggs from hens housed } \\
\text { above } 5,000 \text { feet }(1,500 \mathrm{~m}) \text {. }\end{array}$ & $\begin{array}{l}\text { Avoid high altitude or add oxygen } \\
\text { to the incubator. }\end{array}$ \\
\hline
\end{tabular}

\section{OBSERVATION: OVER 0.5\% DEAD FROM DAY 4 TO TRANSFER}

\begin{tabular}{|l|l|l|}
\hline Problem & Causes & Remedies \\
\hline Many dead embryos. & $\begin{array}{l}\text { Improper incubator tem- } \\
\text { perature. }\end{array}$ & $\begin{array}{l}\text { Check thermometer for accuracy; } \\
\text { set temperature at } 99.5^{\circ} \text { to } 100^{\circ} \mathrm{F} \\
\left(37.5^{\circ} \text { to } 37.8^{\circ} \mathrm{C}\right) .\end{array}$ \\
\cline { 2 - 3 } & Power failure. & $\begin{array}{l}\text { If power fails, open machine until } \\
\text { power is restored. }\end{array}$ \\
\cline { 2 - 3 } & Improper turning. & $\begin{array}{l}\text { Turn eggs three or more times } \\
\text { each day. }\end{array}$ \\
\cline { 2 - 3 } & Eggs from inbred stocks. & Avoid inbreeding. \\
\cline { 2 - 3 } & $\begin{array}{l}\text { Poor ventilation of hatch- } \\
\text { ery or incubator. }\end{array}$ & Provide proper air exchange. \\
\cline { 2 - 3 } & Diseased or infected eggs. & $\begin{array}{l}\text { Use eggs from healthy flocks; seek } \\
\text { veterinary assistance; do not wash } \\
\text { eggs in cold water. }\end{array}$ \\
\hline
\end{tabular}




\begin{tabular}{|c|c|c|}
\hline Problem & Causes & Remedies \\
\hline \multirow[t]{4}{*}{$\begin{array}{l}\text { Embryos die before } \\
\text { pipping. }\end{array}$} & $\begin{array}{l}\text { Low-temperature incubating } \\
\text { conditions; relative humidity too } \\
\text { high. }\end{array}$ & $\begin{array}{l}\text { Maintain } 99.5^{\circ} \mathrm{F}\left(37.5^{\circ} \mathrm{C}\right) \text { dry-bulb and } \\
86^{\circ} \mathrm{F}\left(30.0^{\circ} \mathrm{C}\right) \text { wet-bulb temperature in } \\
\text { fan-ventilated setter. }\end{array}$ \\
\hline & Infected eggs. & $\begin{array}{l}\text { Do not wash eggs in cold water. Use } \\
\text { wash water temperature of } 110^{\circ} \text { to } \\
120^{\circ} \mathrm{F}\left(43.3^{\circ} \text { to } 48.9^{\circ} \mathrm{C}\right) \text {; set only nest- } \\
\text { clean eggs. }\end{array}$ \\
\hline & Poor nutrition of breeder flock. & $\begin{array}{l}\text { Check breeder diet; nearly all known } \\
\text { vitamins and minerals, if absent or in } \\
\text { short supply, can cause late mortality } \\
\text { and poor chick quality. }\end{array}$ \\
\hline & $\begin{array}{l}\text { Presence of lethal genes in } \\
\text { stock. }\end{array}$ & Use vigorous strains; avoid inbreeding. \\
\hline $\begin{array}{l}\text { Embryos weak and fail } \\
\text { to pip or pip weakly. }\end{array}$ & Vitamin E deficiency. & $\begin{array}{l}\text { Use fresh feed or supplement Vitamin } \\
\text { E in water (48 IU Vitamin E/gal water). }\end{array}$ \\
\hline \multirow[t]{2}{*}{$\begin{array}{l}\text { Many pips stuck to } \\
\text { shell. }\end{array}$} & $\begin{array}{l}\text { Hatcher relative humidity too } \\
\text { low. }\end{array}$ & $\begin{array}{l}\text { Maintain } 90^{\circ} \mathrm{F}\left(32.2^{\circ} \mathrm{C}\right) \text { wet-bulb tem- } \\
\text { perature after pipping begins. }\end{array}$ \\
\hline & $\begin{array}{l}\text { Excessive residual albumen } \\
\text { caused by high relative humidity } \\
\text { and/or low temperature incuba- } \\
\text { tion. }\end{array}$ & $\begin{array}{l}\text { Check thermometers and thermostats; } \\
\text { monitor temperature and relative } \\
\text { humidity. }\end{array}$ \\
\hline \multirow[t]{3}{*}{$\begin{array}{l}\text { Chicks pipped and } \\
\text { dead. }\end{array}$} & Disease. & $\begin{array}{l}\text { Use healthy stock; seek veterinary } \\
\text { advice. }\end{array}$ \\
\hline & $\begin{array}{l}\text { Overheating in hatcher; low } \\
\text { hatcher relative humidity. }\end{array}$ & $\begin{array}{l}\text { Check hatcher temperature and rela- } \\
\text { tive humidity. }\end{array}$ \\
\hline & Nutritional deficiency. & $\begin{array}{l}\text { Feed balanced diet; see Nutrient } \\
\text { Requirements of Poultry } 1994 .\end{array}$ \\
\hline Malpositions. & Eggs set small-end up. & $\begin{array}{l}\text { Position eggs properly in trays (large } \\
\text { end up or horizontal). }\end{array}$ \\
\hline $\begin{array}{l}\text { Chicks hatch too early, } \\
\text { are thin and noisy. }\end{array}$ & $\begin{array}{l}\text { Temperature too high during } \\
\text { incubation period. }\end{array}$ & $\begin{array}{l}\text { Check thermometer; } 1^{\circ} \mathrm{F}\left(0.6^{\circ} \mathrm{C}\right) \text { in } \\
\text { excess of } 99.5^{\circ} \mathrm{F}\left(37.5^{\circ} \mathrm{C}\right) \text { will cause } \\
\text { hatch approximately } 24 \text { hours early. }\end{array}$ \\
\hline \multirow[t]{2}{*}{$\begin{array}{l}\text { Chicks hatch late, are } \\
\text { soft and lethargic. }\end{array}$} & $\begin{array}{l}\text { Temperature too low and rela- } \\
\text { tive humidity too high during } \\
\text { incubation period. }\end{array}$ & $\begin{array}{l}\text { Check thermometer; } 1^{\circ} \mathrm{F}\left(0.6^{\circ} \mathrm{C}\right) \text { below } \\
99.5^{\circ} \mathrm{F}\left(37.5^{\circ} \mathrm{C}\right) \text { will cause late hatch. }\end{array}$ \\
\hline & Old eggs. & $\begin{array}{l}\text { Set only fresh eggs; allow extra time } \\
\text { for hatch by setting old eggs early. }\end{array}$ \\
\hline \multirow[t]{3}{*}{$\begin{array}{l}\text { Sudden losses at any } \\
\text { time. }\end{array}$} & $\begin{array}{l}\text { Improper fumigation; use only } \\
\text { approved fumigants and follow } \\
\text { label directions. }\end{array}$ & $\begin{array}{l}\text { Do not fumigate from } 24 \text { to } 96 \text { hours } \\
\text { of incubation. }\end{array}$ \\
\hline & $\begin{array}{l}\text { Mercury spilled in incubator or } \\
\text { hatcher. }\end{array}$ & $\begin{array}{l}\text { Check for broken thermometer or ther- } \\
\text { mostat; clean up all spilled mercury } \\
\text { immediately. }\end{array}$ \\
\hline & $\begin{array}{l}\text { Power or equipment failure or } \\
\text { overheating. }\end{array}$ & $\begin{array}{l}\text { Check incubator temperature at least } \\
\text { twice daily; refer to instruction manual } \\
\text { for proper maintenance procedure. }\end{array}$ \\
\hline
\end{tabular}




\section{GLOSSARY}

blastoderm without embryo (BWE). When candled, a BWE egg shows a blood ring; on breakout there are no visible embryo structures.

blastodisc. The small disc-shaped region on the yolk that contains the egg nucleus.

blood ring. Circular blood remnant visible when an egg is candled; signifies that the embryo has died at a young age.

breakout. The examination of egg contents to determine whether the blastodisc was fertilized or embryonic structures were present.

candled fertility. The percentage of eggs remaining after clears are removed by candling; compare with true fertility.

candled out. Clearing eggs removed from the incubator following candling.

candling. Transluminating an egg with light to determine the presence or absence of a viable embryo or to look for shell defects before setting.

clears. Incubated eggs that appear clear when candled, indicating that they do not contain a live embryo.

cystic embryo. Embryo that dies early in gestation; the broken-out appearance is similar to a BWE except that embryo tissue is visible.

dry-bulb temperature. Temperature measured with a standard thermometer or electronic sensor; compare with wet-bulb temperature.

embryo. An organism in the early stages of its development before hatching.

fertile, no development (FND). Rarely diagnosed condition in which the blastodisc was fertilized but died before the egg was laid or before growth could be initiated in the incubator.

fertile, preovipositional death. Rarely diagnosed condition characterized by a blastodisc that appears to be fertile but dies before the egg is laid by the hen.

germ, germinal disc. Fertilized blastodisc; the embryo has about 50,000 cells when the egg is laid.

hatch, percent hatch, hatching percent, hatch of total. Percentage of all eggs set that hatch whether they were fertile or not (a typical hatch might be $80 \%$ to $90 \%$ ).

hatch of fertile eggs, hatchability. Percentage of fertile eggs that hatch (should be above $85 \%$ ).

hatcher. Machine used to maintain proper conditions for embryos during the final few (usually 3) days before hatching.

inbred. Birds or flocks that have some degree of inbreeding.

inbreeding. The result of mating closely related birds, such as father to daughter or brother to sister. As inbreeding increases, the ability of the stock to reproduce usually declines.

incubation. Maintaining the temperature and humidity needed to initiate embryo growth and hatching of avian eggs by a female or using a machine.

incubator. Machine that maintains proper conditions for incubating or setting avian eggs. Also referred to as a setter. 
malposition. Hatching embryo in any position except the head under the right wing positioned in the large end of the shell; for example, the head under the left wing or the head between the legs.

parthenogenesis. Development of an egg without fertilization, which occurs at low levels in chickens and turkeys. Embryos usually die; if the embryo hatches it will be a male with a diploid $(2 \mathrm{n})$ number of chromosomes.

pip. Egg in which the chick has broken the shell in an attempt to hatch; also, the act of breaking the shell. Chicks may die after pipping or may be unable to get out of the shell.

positive development (PD). Eggs are candled out as clears because there is no blood formation; the germ was fertile, but it died soon after cell growth resumed when the egg was warmed above $80^{\circ} \mathrm{F}\left(26.7^{\circ} \mathrm{C}\right)$.

relative humidity. Measure of the water vapor or moisture in air; can be determined from the wet-bulb and dry-bulb temperature using a psychometric chart.

set. To place eggs in an incubator or under a female for incubation.

setter. An incubator.

spread. The difference between percent of fertile eggs and percent hatch (a 10\% to $12 \%$ spread is typical for chicken eggs).

true fertility. Percentage of hatching eggs that are fertile. This can be determined only by incubation, candling, and breakout of the clears to determine which eggs were fertile or by breaking out potentially fertile eggs to examine the germinal disc (e.g., a sample might be examined to estimate fertility of a flock).

true infertility. Lack of true fertility.

wet-bulb temperature. Temperature measured by a standard thermometer equipped with a wet sock over the bulb. For accurate measurements, air must be moving over the wet sock to provide evaporation. Electronic sensors are now available to measure the relative humidity of air in incubators and egg storage rooms.

\section{REFERENCES}

Nutrient requirements of poultry. 1994. Washington, D.C.: National Academy Press.

Ernst, R. A. 2004. Hatching egg sanitation: The key step in successful storage and production. Oakland: University of California Division of Agriculture and Natural Resources Publication 8120. Available for free downloading from the Communication Services Web site, http://anrcatalog.ucdavis.edu/pdf/8120/pdf.

\section{FOR MORE INFORMATION}

Visit the ANR Communication Services online catalog at http://anrcatalog.ucdavis.edu. You can also place orders by mail, phone, or FAX, or request a printed catalog of our products from:

University of California

Agriculture and Natural Resources

Communication Services

6701 San Pablo Avenue, 2nd Floor

Oakland, California 94608-1239

Telephone: (800) 994-8849 or (510) 642-2431; FAX: (510) 643-5470

E-mail inquiries: danrcs@ucdavis.edu 
An electronic version of this publication is available on the ANR Communication Services Web site at http://anrcatalog.ucdavis.edu.

\section{Publication 8127}

(C) 2004 by the Regents of the University of California, Division of Agriculture and Natural Resources. All rights reserved.

The University of California prohibits discrimination or harassment of any person on the basis of race, color, national origin, religion, sex, gender identity, pregnancy (including childbirth, and medical conditions related to pregnancy or childbirth), physical or mental disability, medical condition (cancer-related or genetic characteristics), ancestry, marital status, age, sexual orientation, citizenship, or status as a covered veteran (covered veterans are special disabled veterans, recently separated veterans, Vietnam era veterans, or any other veterans who served on active duty during a war or in a campaign or expedition for which a campaign badge has been authorized) in any of its programs or activities.

University policy is intended to be consistent with the provisions of applicable State and Federal laws.

Inquiries regarding the University's nondiscrimination policies may be directed to the Affirmative Action/ Staff Personnel Services Director, University of California, Agriculture and Natural Resources, 300 Lakeside Drive, 6th Floor, Oakland, CA 94612-3550, (510) 987-0096. For a free catalog of other publications, call (800) 994-8849. For help downloading this publication, call (530) 754-5112.

pr-3/04-SB/CR

ISBN 978-1-60107-306-8

This publication has been anonymously peer reviewed for technical accuracy by University of California scientists and other qualified professionals. This review process was managed by the ANR Associate Editor for Animal, Avian, Aquaculture, and Veterinary Sciences. 